\title{
The Influence of Social Sciences On The Professionalization of Social Work: A Case Study In A Treatment Team With Consumers Of Psychoactive Substances
}

\author{
Joana Brinca. PHD. \\ Department of social and Human sciences. \\ Instituto Politécnico de Viseu - Escola Superior de Tecnologia e Gestão de Lamego. \\ Av. Visconde Guedes Teixeira. 5100 - 074 Lamego \\ Nídia Menezes. PHD. \\ Department of social and Human sciences. \\ Instituto Politécnico de Viseu - Escola Superior de Tecnologia e Gestão de Lamego. \\ Av. Visconde Guedes Teixeira. 5100 - 074 Lamego
}

\begin{abstract}
Speaking in social services implies talking about the social concept, which is an indissociable social issue and social problems arising from industrialization, urbanization and proletarization. According to ander-egg (1995b, pp. 152-153) "by the influence of sociology [and other social sciences], the term" social came to be used with two meanings: a generic and broad, referring to the global society [and the collective characteristics of a particular population] (...); and another restricted, alluding to particular questions of sociological analyses, such as social structure, social change, stratification, mobility and social participation ", that is, the individual in and in society. In the decade of 60 the "social" integrated as a partner the economic issue and improvement of the quality of life/social welfare. It was within this logic of thought that was associated with the concept "social sectors" (1995b, pp. 152-153) such as: education, housing, health, social security, culture, politics, employment. In turn, in the decade of 70, there is a change in the current paradigm. We witnessed a progressive passage/attempt to pass a tripartite intervention method to an integrated intervention method. That is, the positivism applied to the social sciences is questioned giving place to the emergence of other more integrated and more flexible paradigms highlighting the importance and influence of the social sciences in the analysis of contextual variables of social situations/ problem presented, as can be seen by the case study on the professional practice of the social worker in a treatment team of portugal, with consumers of psychoactive substances, under the opioid substitution program.
\end{abstract}

Keywords: Social Ciences; Social Service; Treatment Team; Psychoactive Substance Users.

\section{LITERATURE REVIEW}

According to Iamamoto (1998, p. 27) (...) "The social service has in the social issue the basis of its foundation as a specialization of work." Therefore, the emergence and institutionalization of Social services followed social transformations at various levels: economic, social, political, cultural, intervening with the individual and families, groups and communities.

As Parton said (2000) The new social practices (to address the social challenges and the more traditional practices of assistentialism, the strategies of signaling, reception, attendance, social and technical aids (Vieira, 1985) (...) were given "in the A hybrid, the "social", situated between the public and private sphere, and produced by the new relations established between law, administration, medicine, School and Family "(Parton, 2000, p. 5) 
The Social service has a hybrid theoretical and methodological body, Mestiço, when it uses the influence of the social and human Sciences in the assessment of needs and competencies throughout the diagnostic evaluation, therefore requires a descriptive analysis, Interpretative, systemic, being an instrument (Social diagnosis) Identitary of the professional practice of social workers. The Social service is recognized as the ability to cross, relate and integrate theories and knowledge from various knowledge sciences or disciplinary areas in solving concrete problems, crossing the micro, meso and practice dimensions, in "Punctual, sectoral, categorical and global" intervention (Bouquet \& Garcette, 2005, p. 18-19).

According to Bouquet \& Garcette (2005, p. 18-19), the assistance provides differentiated levels of intervention, depending on the type of target audience that can be typified between the "punctual", "categorial", "sectoral" and "global". Punctual is understood as the most individualized and reparative type of intervention that concerns the failures of a particular social system. The "categorial" intervention when addressing groups from individuals, children, the elderly and immigrants, the "sectoral" intervention when it specifies a certain social problem that needs to be resolved and the "global" intervention when for example intervenes in a The logic of improving living conditions through the creation of social equipment.

The authors Kamerman and Dolgoff (1984) identify two dimensions and levels of intervention: "First to the level of intervention for practice; And secondly, a view of the specific fields of the social sciences "(p. 122).

Within the verified dimensions we can distinguish two levels of intervention:

- Micropractice involving individuals, families, small groups, organizations and communities;

- Macropractice, involving the city, the state, the region, the federal scope or any level of macrosystem.

"The social workers who deal with Microsystems have harnessed the knowledge of sociology and social psychology related to the theory of roles, the influences of class, ethnicity and cultures, the impact of racism, the functioning of the family nucleus, kinship systems, and others "(Kamerman and Dolgoff, 1984, p. 124-125).

In the intervention with the small groups, we highlight the anthropological studies to better understand the cultural influences on the personality, family and functioning of the group, as well as the influences of the past (p. 125).

Anna Freud and Erikson were some of the authors who focused on the study of human development during the life cycle (adolescence, adulthood and old age), although Freud has highlighted more about early childhood and Piaget with the development Cognitive impairment from childhood to adolescence (p. 127).

For the beahviorists, human behavior is linked to the environment as well as the approach of behavioral change, with Pavlov's "stimulus-response theory of learning" for non-reflective behavior (p. 123).

The general theory of the systems also highlights, assuming emphasis on micropractice, since "the" systems "(such as school, employment, medical care or institution) have a continuous impact on customers and vice versa, making much more comprehensible the Trends for 
advocacy, and the expansion of evaluation techniques by professionals "(Kamerman and Dolgoff, 1984, p. 127).

The theories of communication and its three distinct areas are also a reality in the practice of Social work. The linguistic, the paralinguistic and cybernetics that "show how different language structures determine ways of thinking and the importance of non-lexical vocalization and non-verbal human communication" (p. 130) are noteworthy. These distinct areas aim to reduce the misunderstanding of specific cultural influences, increasing understanding, sensitivity and empathy towards the intervention subjects/recipients of our intervention, including with People with psychiatric disorders.

In the study of Macropractice, three social sciences should be taken into consideration: sociology, economics and political science.

In the opinion of Kamerman and Dolgoff (1984) "Sociology was historically the first source of knowledge for the practice of social service (...) Nowadays, for the profession of social service, passionate about the psychoanalytic understanding of human problems, the sociological theory helped to take back into account the environmental influences on human behavior. Sociology, therefore, provides valuable knowledge to social workers with the theory of small groups and family, normative behavior and the nature of societal conditions and problems "(p. 139).

The relationship between Social services and economics is not very old. Only from the decade of 60 and through Eveline Burns is an interrelationship between the economy and Social service, historically more channelled to the financing of social welfare programs and the development of Income maintenance programs (p. 148).

We highlight some authors such as Cohen "among the few social workers who recognized the importance of the economy and political factors and advised the social workers to study the new dynamic concepts that emerge from the economy and science Politics, as well as sociology, social psychology, and cultural anthropology. Mr Feldman Nliaou the impact of the economy on family life in relation to the need to draw up a family budget. Kahn discussed the practice of social service in a broader context, by mentioning the Inter of the economy with social factors "(p. 149).

Political science is a social science that is important for Social work in that its conceptions when applied in practice/reality originate social implications, which are reflected in the objectives and decisions of political decision-making.

The functions performed by the Social worker in a given professional/institutional context where professional practice is unfolding, interrelating with the addressees of their action/intervention subjects, makes it necessary to Social service is provided with multiple theories and knowledge in both micro and macropractice.

That is, "an understanding of ecological systems will encourage a systematic collection of information, outlined in factual observation and evidence, taking into account intra-and interpersonal factors alongside social, economic and Situations in which an assessment is required "(Baldwin and Walker, 2005, p. 40).

According to the aforementioned authors, there is a network of interactive factors that influence individual situations. 
Figure a) Network of interactive factors influencing individual situations.

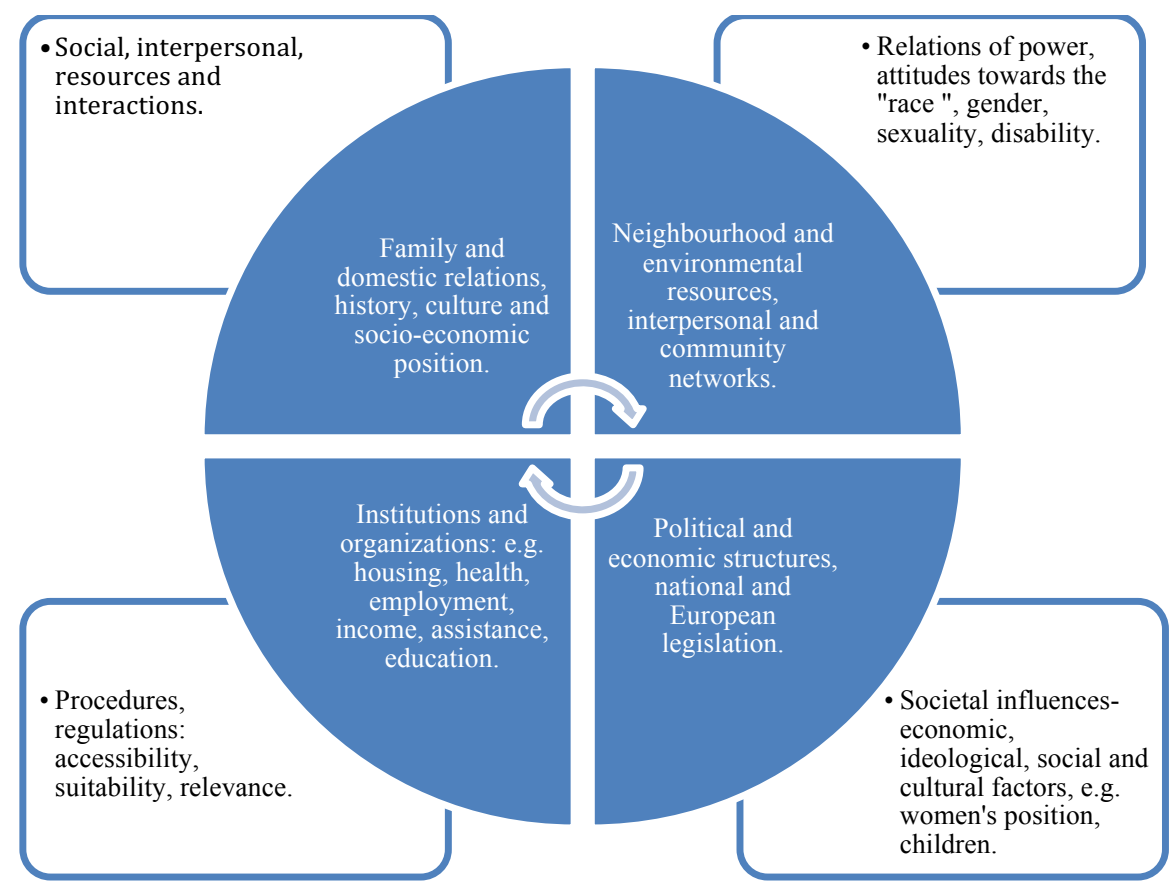

Source: Baldwin and Walker (2005) in Sousa; D'Almeida, 2016, p. 47).

According to Santos (2009, p. 70) "In the scientific community, any knowledge that possesses the degree of development necessary to produce a specific systematic understanding and a method, also specific, is considered an autonomous scientific discipline. But only the disciplines that dedicate themselves to the specialized study of a part of the social nature of the human being, or of any activity that it develops as a member of a social group, are considered social sciences."

According to Megías (2004), the Social service has two categories of knowledge:

(...) propositional knowledge [contemplating] descriptive, diagnostic and prospective theories of the social situations subject to professional work; (...) [and] operational knowledge: [concerning] technical systems of intervention built and jobs in these same situations "(2004, p. 280).

For Sibeon (1990) There are two types of theory: Theories of how to do social service and theories about the client's world (in Payne, 2006, p. 6-7).

The first theories are also known as the theories of practice or "practice theory" with emphasis on cognitive-behavioral theories, for intervention models in crisis, psychosocial model, taskcentered model, model of resolution of problems, ecological and systemic model (Payne, 2002; Viscarret, 2007; Ranquet, 1996).

In turn, the theories of the client world refer to the concrete problems of life in society and that promote knowledge for the Social service: poverty, domestic violence, social exclusion, unemployment, school failure, Bulliyng, ageing, among Other phenomena/social realities.

For Carvalho (2016) and with regard to the theoretical and methodological dimension of the Social service "knowledge and theory in Social service are multidisciplinary and eclectic" (p. 18). It refers to theories for action and action. In this article we make an analogy between 
theories in action, crossing them with theories of how to do social service, and the theories of the client's world with theories for action (Sibeon, 1990 in Payne, 2006, p. 6-7).

Carvalho (2016) affirms that in the Social service we use two types of knowledge: the knowledge acquired and the knowledge Used (p. 21). At the intersection of the two types of knowledge we highlight the theoretical knowledge that concerns the abstract theories, where they stand out:

- Abstract theories adapted, or developed or adapted from other disciplines such as sociology, psychology, economics, organizational theories...

- Abstract theories that enable the analysis of the role and tasks of social workers: theories of roles; The tasks and the dual purpose of the Social service (caring and controlling).

- Abstract theories that enable the analysis of practices related to: generalist competencies and interventions; Practice areas; approaches to practice; Perspectives founded on values.

In addition to the theories identified, we still have factual knowledge, that is, facts, statistics, evidences and researches that are inserted in:

Laws. Knowledge of legal principles and relevant legislation;

- Social policy. Knowledge of relevant social policy;

- Organizations and agencies. Knowledge of the policy of organizations, procedures and practices;

Problems. Knowledge of specific social problems.

- People/citizens. Knowledge about specific groups.

Practical knowledge is that knowledge acquired through practical experience - wisdom of practice (Carvalho, 2016, p. 21).

Netto (1995) considers that the theoretical specificity of the Social service relates not to the professional practices developed by the social worker, but "to the objects of their practices" ( $p$. 15).

For Santos (2012) "The legitimacy of the profession of social work will be based, then, on the relationship that the Social service can establish between its practice and the objects of its practice, combining three levels of competence: the theoretical competence (implies the Indepth knowledge of the dynamics of social processes), technical competence (appropriation of interventional and operative procedures accumulated in the tradition of the social and Human sciences) and political competence (ability to evaluate conjunctures, To articulate alliances and to learn the social meaning of their work) "(p. 129).

\section{METHODOLOGY}

In order to better understand the interconnection between the Social service and the other social sciences, we will describe the professional practice of the Social worker in a treatment team of Portugal, with consumers of psychoactive substances, under the program of Opioid substitution, i.e. Under the Methadone Maintenance Program.

\section{GOALS}

- Identify the profile of the users of a treatment team, in an opioid substitution program (for this purpose, a study was elaborated for three months (March, April, May 2019).

- Analysis of the professional practice of social workers in a treatment team and their work instruments.

- Identify dimensions of analysis of the instruments used by the social workers. 


\section{DISCUSSION OF RESULTS}

In a universe of 299 users in the methadone program, the following were found: $57 \%$ of the users enrolled in the opioaceous substitution program are single and only $28 \%$ are married.

In relation to the household, it is emphasized that individuals reside with their parents, presenting $20 \%$ of them residing alone and only $1 \%$ who reside with friends. The majority of users are beneficiaries of social insertion income. The ages of consumption are quite varied, highlighting the beginning of the consumption of illicit substances at 18 years of age. The predominant substances are: heroin, cocaine and cannabis. The most practiced mode of consumption is endovenous, followed by smoked and finally inhaled. Regarding health, there are many users who have health problems: Hepatitis B and C, tuberculous and HIV.

The treatment teams consist of psychologists, nurses, physicians, social workers and psychosocial technicians, developing various types of actions, ranging from consultations of psychosocial approaches, psychotherapeutic support, medical consultations, Therapeutic programs using opioid agonists or opioid antagonists, consultations aimed at children and young people, pregnant women, patients with mental pathologies and also to relatives of service users and, lastly, nursing consultations.

The professional practice of the Social worker in a treatment team has the following steps: screening; Patient and/or family care; Individual psychosocial support and family approach; Community Support (network work).

In screening, the Social service integrates a multidisciplinary team in which it emphasizes in its specificity the psychosocial perspective of the patient and/or family, or other involved. The first concern of the Social service is to acquire a global knowledge of the problem of the situation of each user.

In the care of the families and/or the patient, the Social worker intends, in the case of the strict request only of the family and in the situation of consumption of psychoactive substances, access to the understanding of their request in the sense of essential clarification. In the case of the request of the family with the user, directed already for treatment, the Social worker, following a follow-up intervention, verifies whether the same, intends to integrate a therapeutic project, centralizing its specific intervention, if the case, in its context in order to better use the appropriate methodological tools or strategies, which are considered more pertinent, i.e. a work of systemic approach and/or networking in collaboration with all local structures considered necessary to resolve each case.

This type of intervention should be carried out in line with the therapeutic team.

Finally, with regard to types of intervention in the community, the Social service should be increasingly facing a work of joint collaboration through other professionals, who in some way knows the reality of each case closely. The objectives will always be better achieved if the applied methodology is in line with the reality, that is, with the social system of the surrounding environment.

In the follow-up of social cases, social workers use various forms (Social information, Individual insertion plan, connection form (for isolated users and who receive other social support, such as medication) that Comtemplam The following areas/dimensions of analysis: -Identification (name, nationality, Social security identification number and address); 
- Familial situation (household information, date of birth, marital status, literary qualifications, occupation, profession);

- Family dimension (relations with the nuclear and enlarged family);

- Socio-economic dimension (elements of the aggregate and provenance thereof, fixed monthly expenses);

- Habitational Dimension (rented, transferred, own, lease, habitability);

- Health dimensions (health problems with indication where it is being monitored, healthrelated expenditures and proven medical statement);

- Additive behaviors and current dependencies (substance, start and end of consumption, current situation);

- Judicial situation;

- Intervention Plan;

Health (comply with the therapeutic project delineated with the therapeutic team, consolidate the abstinence of unprescribed drugs);

Citizenship (working personal, social skills to control situations that generate conflict; Strengthening of defence mechanisms and tolerance to frustration; requires social support); Occupation of free time (prevention of deinsertion, attending recreational activities).

- Identification and support needs (purpose, amount, duration and rationale).

For example: For an isolated individual, without family back and with a very fragile health, which does not allow him to pursue professional activity, economic support is requested under the $\mathrm{X}$ and $\mathrm{Y}$ rupee to make their needs in the face of expenses with Medicines and transports to move whenever necessary to the various services that accompany it.

\section{CONCLUSIONS}

The Social worker works in order to promote a balance and well-being of users, using techniques such as social Information, connection cards, follow-ups to consultations, registration of follow-ups.

The Social worker plays a fundamental role, because all individuals who resort to this service need the intervention of the technician in order to restructure their life, and for that reason, a holistic, planned and Structured in order to bridge all the needs and problems that the individual faces.

\section{References}

Ander-Egg, E. (1995b). “Introdução ao Trabalho Social”. Petrópolis: Editora Vozes.

Baldwin, N. and Walker, L. (2005). “Assessment”. In Adams, R., Dominelli, L. and Payne, M. (eds). "Social Work Futures - crossing boundaries, trnasforming practice". Basingstpke: Palgrave Macmillan.

Bouquet, B. \& Garcette, C. (2005). “Assistente Social Aujourd'hui”. 2ª edição. Paris: Éditions Maloine.

Carvalho, M. I. (2016). “Érica Aplicada ao Serviço Social. Dilemas e Práticas Profissionais”. Parctor.

Iamamoto, M. (1998). “O Serviço Social na Contemporaneidade: Trabalho e Formação Profisisonal”. São Paulo. Cortez Editora.

Kamerman, S.; Dolgoff, R. (1984). “Conhecimento para a prática: Ciências Sociais no Serviço Social”, in Kahn, Alfred, J., "Reformulação do Serviço Social”, S. Paulo. Livraria Agir Editora (p. 116 - 168).

Megías, R. (2004). “Natureza, Objetos, Objetivos Y Funciones del Trabajo Social”, García, Tomás Fernández. \& Bracho, Carmen Alemán (cood), "Introduccíon al Trabajo Social”. Madrid: Alianza Editorial, pp. 277 - 312.

Netto, J. (1995). Capitalismo Monopolista e Serviço Social. São Paulo: Cortez

Parton, N. (2000). "Social Theory, Social change and Social Work. Na Introduction"., Parton, M. (ed), "Social Theory, Social Change and Social Work", 3rd., London/New York: Routledge; pp.4 - 18.

Payne, M. (2002). “Teoria do Trabalho Social Moderno. Coimbra. Quarteto Editora. 
Payne, M. (2006). What is professional social work? 2nd edition. Bristol: Policy Press.

Santos, C. (2009). Retratos de uma Profissão: a Identidade Profissional de Serviço Social. Coimbra: Editora Quarteto.

Santos, C. (2012). Organização da Prática Profissional do Serviço Social em Modelos de Intervenção Social. Lusíada. Intervenção Social, Lisboa, n.o 39 [1ํㅗ semestre de 2012]

Santos, M. I. R. S. (2009). “O Discurso Histórico sobre o Serviço Social em Portugal”. Universidade Católica Portuguesa.

Sousa, P.; D’Almeida, J.L. (2016). “Avaliação Diagnóstica na Prática do Serviço Social”. Psicosoma Editora. Editora. 2a Edição.

Ranquet, Du Mathilde (1996). “Los Modelos en Trabajo Social - Intervención com personas y famílias”.Siglo Veintiuno de España Editores, S.A.

Vieira, B. O. (1985). “Metodologia do Serviço Social: contribuição para a sua elaboração.” Rio de Janeiro. Agir Editora.

Viscarret, J. J. (2007). “Modelos y métodos de intervención en Trabajo Social”. Alianza Editorial. 